\title{
Coinfections of Human Immunodefiency Virus and Sexually Transmitted Infections Among HIV Seropositive Pregnant Women at Healthcare Centres in Akure, Southwestern Nigeria
} Ebhodaghe Blessing Itohan1, Ako-Nai Kwashie Ajibade1, Aderoba Adeniyi Kolade², Anderson Winston $\mathrm{A}^{3}$, Kassim Olakunle $\mathrm{O}^{4}$

\section{Abstract}

Background: Sexually transmitted infections (STIs) represent significant risk factors for HIV transmission and adverse fetal complications in pregnancy. We tested 240 pregnant women for their HIV serostatus and for the effects of HIV-STI coinfections on CD4+ cell counts and on HIV plasma viral load. The study was conducted at four antenatal clinics in Akure, Ondo State of Nigeria between November 2014 and December 2015.

Methods: The HIV-1/2 strip was used for preliminary determination of HIV serostatus and this was followed by a confirmatory Abbott enzyme-linked immunosorbent assay (ELISA) procedure. CD4+ T-cell counts were done by cytometric analysis while viral load was determined by COBAS $^{\circledR}$ AmpliPrep TaqMan HIV-1 procedure. Liver enzymes were determined by an automated chemistry analyzer. Detection of hepatitis $B$ virus (HBV), hepatitis C virus (HCV), human papilloma virus- 6 (HPV-6) and herpes simplex virus type-2 (HSV-2) were determined by ELISA. The syphilis VDRL test was done by the rapid plasma reagin procedure, while Trichomonas vaginalis infection was demonstrated by the wet mount procedure. Infections with Chlamydia trachomatis and Neisseria gonorrhoeae were determined respectively by ELISA and by culture on proteose peptone agar supplemented with $5 \%$ serum.

Results: The results show prevalence of STIs in $33.3 \%$ of the 240 study participants; $77.5 \%$ for HIV seropositive and $22.5 \%$ for seronegative subjects. Trichomonas vaginalis constituted the highest isolate
1 Department of Microbiology, Obafemi Awolowo University, Ile-Ife.

2 Department of Obstetrics and Gynaecology, Mother and Child Hospital, Akure.

3 Department of Biology, Howard University.

4 Department of Microbiology, College of Medicine, Howard University, Washington DC, USA.

Contact information:

Kwashie Ajibade Ako-Nai.

Address: Department of Microbiology, Faculty of Science, Obafemi Awolowo University, Ile Ife, Osun State, Nigeria.

झ kwasajibad@gmail.com 
in $50 \%$ of HIV seropositive subjects and $22.2 \%$ for seronegative controls. HIV-HBV coinfection occurred among 7 individuals while HIVHBV-TV coinfection occurred in 4 individuals. The results also showed elevated titers of alanine aminotransferase (ALT), creatinine and total bilirubin liver enzymes in both HIV-HBV coinfection and HBV monoinfection. HIV viral loads were twice as high in HIV-HBV coinfection relative to HBV mono- infection.

Conclusion: The prevalence of STIs was significantly high at 54.4\% among HIV seropositive pregnant women as compared to $14.3 \%$ for HIV seronegative pregnant women. T. vaginalis was the highest isolate at $50 \%$ in HIV seropositive subjects and may therefore be a driving factor for HIV transmission and susceptibility as very few $T$. vaginalis infections were recorded in control subjects.

\section{Keywords}

STDs; Coinfection, HIV, CD4+ Cells, Viral Load, Liver Enzymes, Pregnancy.

\section{Introduction}

Studies have shown that sexually transmitted diseases (STDs) such as Neisseria gonorrhea, Trichomonas vaginalis, Chlamydia trachomatis, human herpes simplex-2 (HSV-2) and human papilloma virus-6 (HPV-6) are significant risk factors for HIV transmission in women [1]. HIV infection in pregnant women may lead to adverse fetal outcomes, while co-infection of HIV with any STI during pregnancy may accelerate the development of fetal and maternal complications [2]. A recent study from Nigeria reported that infection with Trichomonas vaginalis increased the risk of HIV infection, while another study showed an HIV infection rate of $33 \%$ among women with infections of $T$. vaginalis. Studies from Zimbabwe reported that women with a history of genital ulcers and pelvic inflammatory disease were six times more likely to contract HIV than normal individuals [3]. Another study showed that improved STD treatment in a randomized controlled trial in Tanzania reduced the rate of new HIV infections, underscoring the role of STIs in HIV susceptibility. Epidemiological studies from sub-Saharan Africa, Europe and North Ame- rica have suggested that there is approximately a four-times greater risk of becoming infected with HIV in the presence of a genital ulcer such as those caused by syphilis and chancroid [4]. Prevalenc e rates of syphilis as high as 30\% have been described in antenatal women while $4.2 \%$ of women in a population-based study in Tanzania reported a history of genital ulcers [5]. Such co-infections may significantly increase HIV plasma viral load [6]. It was estimated that a 10 -fold increase of plasma HIV RNA resulted in an 81\% increased rate of HIV transmission [7, 8]. About 350-400 million people worldwide are chronically infected with $H B V$, with over a million individuals dying annually from HBV related complications [2]. HIV and HBV are two viruses with similar modes of transmission through sexual contact, mother-to- child transmission (MTCT) in pregnancy, breast-feeding and intravenous drug use [2]. While HIV and HBV have common modes of transmission, HBV has been shown to be about 100 times more infectious [8]. Our study investigated the frequency of HIV-STI coinfections and their effects on CD4+ cell count, HIV plasma viral load and liver enzyme elevations 
among HIV seropositive women who attended antenatal clinics at Akure in Ondo State of Nigeria. It is expected that the findings from our study would enable clinicians to better manage HIV coinfections in both pregnant and non-pregnant women so as to reduce complications that pose a risk for fetal mortality and maternal morbidity.

\section{Methods}

\section{Study centers}

This prospective study was conducted from November 2014 to December 2015 at four antenatal health care centers at Akure in Ondo State, Nigeria. The study included 240 participants, with 114 HIV seropositive and 126 seronegative women in their third trimester of pregnancy. The mean ages for the seropositive and seronegative women were 31.81 and 29.05 years respectively. Approval for the study was obtained from the Ondo State Hospital Management and Ethics committee, while informed consent was received from all participants following questionnaire responses and examination of case files managed by the attending physicians.

\section{Inclusion Criteria}

Informed consent, pregnancy in the third trimester and participation in the highly active antiretroviral therapy (HAART) were criteria for inclusion in the study. There was no age restriction for participation, as all subjects were required to keep all physician appointments throughout the study.

\section{HIV screening}

Blood was collected by venupuncture from each participant. A measured small aliquot was applied onto the HIV-1/2 strip (Determine Test, Alere, UK) for preliminary determination of HIV serostatus. Confirmatory test for HIV infection was performed using an ELISA procedure (Abbott Laboratories, Chicago, IL, USA).

\section{Immunological Assessment}

CD4+ cell counts were carried out by standard cytometric procedure following manufacturer's instructions (CyFlow SL-3, Partec, Germany ${ }^{\circledR}$ ), and with the establishment of a baseline cell count [10]. The counts were repeated at 3 and 6 months later.

\section{Viral load measurement}

Serum aliquots from the whole blood collection were also used for the HIV viral load assessment. Serum was separated from whole blood by centrifugation at room temperature within 6 hours of blood collection, aliquoted, and frozen at $-70^{\circ} \mathrm{C}$ until processing for viral load measurement. The viral load (plasma HIV RNA copies) which quantifies the viral burden of HIV in the blood was assayed only in HIV seropositive subjects. The COBAS $^{\circledR}$ AmpliPrep TaqMan HIV-1 Qual test (version 3.2 series 3.3) kit was employed for the assay [11].

\section{Sexually transmitted infections (STIs)}

Some sexually transmitted infections (STIS) among the study participants were determined using sera from both HIV infected and HIV non-infected pregnant women. Only clear non- haemolysed specimens were used. Specimens were brought to room temperature after being thawed. An automated chemistry analyser (Vitros 350) was employed for determination of liver enzymes following manufacturer's instructions. A modified ELISA method was used for detection of hepatitis B virus (HBV), hepatitis C virus (HCV), human papilloma virus-6 (HPV-6) and herpes simplex virus type-2 (HSV-2). A positive HBV infection was indicated by the demonstration of hepatitis B virus surface antigen (HBsAg). In this procedure, two drops of plasma were transferred to the cassettes containing coated antigen (Abon Biopharm (Hangzhou) Co. Ltd, Hangzhou, China). Thereafter, a drop of buffer (reagents A and B) was added to the cassettes and the assay was timed for 10 -20 minutes and visually observed for a formation of two red colored bands as an indication of a positive test. The rapid plasma reagin test (VDRL) 
was used for the detection of infection with Treponema pallidum, the causative agent of syphilis. $T$. vaginalis was detected by preparing a wet smear on a clean grease-free slide with a drop of sterile normal saline and high vaginal fluid sample collected from the subjects. Each participant presenting with $T$. vaginalis was initially examined for clinical symptoms of yellow discharge, abnormal vaginal odour, vulval itching and signs of colpitis macularis ("strawberry cervix") purulent vaginal discharge and vulvar erythema. While sensitivity of symptoms and signs is relatively low, nonetheless, clinical manifestations are routinely used to identify patients for whom wet mount examination would likely have low yield. Subsequently, the wet mount slide was examined under the microscope for highly motile tiny spear shaped flagellates with an axostyle. This slide examination was performed within 10 to 20 min of sample collection.

The presence of Chlamydia trachomatis in high vaginal swab sample was determined by an enzyme immunosorbent assay (EIA) using cervical mucus obtained from the vaginal posterior fornix of each subject. Each sample was introduced into a cassette containing coated antigen, rinsed by buffer (reagents $A$ and $B$ ), processed according to the instructions of the manufacturer (ABON, Abon Biopharm (Hangzhou) Co., Ltd., Hangzhou, China) and visually observed also for a formation of two colored bands as an indication of a positive test.
Similarly, high vaginal swab was collected from the posterior fornix from each pregnant subject by the attending physician using sterile bivalve speculum (Changzhou Huankang Medical Devices Co. Ltd, Changzhou City, China) and sterile cotton-tipped applicator (Evepon Industrial Limited, Onitsha, Anambra, Nigeria) into freshly prepared sterile thioglycollate medium and incubated at $37^{\circ} \mathrm{C}$ for 24 $\mathrm{h}$ for growth. Thereafter a loopful of the sample was streaked onto freshly prepared agar plates (proteose peptone agar supplemented with $5 \%$ serum) for isolation of $N$. gonorrhoeae. The organism was identified by sugar fermentation test that included glucose, maltose, sucrose and lactose. Only gram negative diplococci isolates with bean-shaped colonies that were also positive for glucose fermentation were confirmed as $N$. gonorrhoeae.

\section{Statistical Analysis of Data}

Statistical evaluation was done using student $t$ - test and one- way analysis of variance (ANOVA) with $p$ $\leq 0.05$ as a measure of statistical significance. SPSS (Chicago, IL, SPSS Inc., 2007) version 17.0 for Windows ${ }^{\circledR}$ was used to perform the analysis.

\section{Results}

Tables 1 and 2 show the distribution of sexually transmitted infections (STIS) among HIV seropositive and seronegative pregnant women in the study po-

Table 1. Profile of sexually transmitted infections in relation to age among HIV seropositive pregnant women.

\begin{tabular}{|l|c|c|c|c|c|c|c|c|c|}
\hline \multicolumn{1}{|c|}{ Age Range } & $\begin{array}{c}\text { No of Subjects } \\
\text { With STls }\end{array}$ & TV & HBV & HCV & HSV-2 & HPV-6 & VDRL & $\begin{array}{c}\text { Chlamydia } \\
\text { trachomatis }\end{array}$ & $\begin{array}{c}\text { Neisseria } \\
\text { gonorrhoeae }\end{array}$ \\
\hline$<19$ & 0 & - & - & - & - & - & - & - & - \\
\hline $20-25$ & 3 & 1 & - & - & 2 & - & - & - & - \\
\hline $26-31$ & 20 & 11 & 3 & - & 2 & - & 3 & 1 & - \\
\hline $32-37$ & 32 & 16 & 2 & - & 1 & 5 & 2 & 1 & 5 \\
\hline $38-43$ & 7 & 3 & 2 & - & - & 1 & 1 & - & - \\
\hline Total & 62 & 31 & 7 & - & 5 & 6 & 6 & 2 & 5 \\
\hline
\end{tabular}


Table 2. Profile of sexually transmitted infections in relation to age among HIV seronegative pregnant women.

\begin{tabular}{|l|c|c|c|c|c|c|c|c|c|}
\hline \multicolumn{1}{|c|}{ Age Range } & $\begin{array}{c}\text { No of Subjects } \\
\text { With STls }\end{array}$ & TV & HBV & HCV & HSV-2 & HPV-6 & VDRL & $\begin{array}{c}\text { Chlamydia } \\
\text { trachomatis }\end{array}$ & $\begin{array}{c}\text { Neisseria } \\
\text { gonorrhoeae }\end{array}$ \\
\hline$<19$ & 1 & - & - & - & - & 1 & - & - & - \\
\hline $20-25$ & 5 & 1 & 1 & - & 1 & 1 & - & 1 & - \\
\hline $26-31$ & 7 & 3 & 1 & - & - & - & 1 & 1 & 1 \\
$32-37$ & 4 & - & 0 & - & - & - & 1 & 2 & 1 \\
$38-43$ & 1 & - & 1 & - & - & - & 0 & 0 & 0 \\
\hline Total & 18 & 4 & 3 & - & 1 & 2 & 2 & 4 & 2 \\
\hline
\end{tabular}

pulation. Diagnostic tests showed that 62 (54.4\%) of the 114 seropositive women were positive for STIS, compared to 18 (14.3\%) of the seronegative women. The vaginal wet mount procedure was used to demonstrated the presence of $T$. vaginalis infection in 31 (50\%) of the 62 HIV seropositive women who had STIS, compared to four (22.2\%) of the 18 seronegative women with STIS. Our ELISA procedure also revealed HBV infection in seven (11.3\%) and HSV-2 infection in five (8.0\%) as well as HPV-6 in six $(9.7 \%)$ of the seropositive women. On the other hand, the results in Table 2 show that the numbers and the overall percentages of seronegative women who had HBV, HSV-2, HPV-6, N. gonorrhoeae and syphilis were significantly lower than in those who were HIV seropositive. Among the seronegative pregnant women with STIs, $16.6 \%$ had HBV, only one had HSV-2 infection and two had HPV- 6 infections. Proteose peptone agar and sugar fermentation cultures revealed $N$. gonorrhoeae infection in five $(8.0 \%)$ of the seropositive pregnant women. The VDRL test demonstrated T. pallidum syphilis infection also in six $(9.7 \%)$ of the seropositive women. Only two (3.2\%) of the seropositive women were positive for Chlamydia trachomatis infection. On the other hand, only two of the seronegative women had $N$. gonorrhoeae infection while another two were positive for the syphilis test. HCV infection was not detected in any of the study participants. Tables 1 and 2 also show the distribution of STIS
Table 3. Prenatal and postnatal CD4+ cell counts and HIV viral load in HIV seropositive pregnant women.

\begin{tabular}{|c|c|c|c|c|c|}
\hline \multicolumn{4}{|c|}{ Prenatal } & \multicolumn{2}{|c|}{ Postnatal } \\
\hline $\begin{array}{l}\text { Age } \\
\text { group }\end{array}$ & \multirow{2}{*}{ No. } & $\begin{array}{l}\text { CD4+ } \\
\text { Counts }\end{array}$ & $\begin{array}{l}\text { HIV viral } \\
\text { load }\end{array}$ & $\begin{array}{l}\text { CD4+ } \\
\text { counts }\end{array}$ & $\begin{array}{l}\text { HIV viral } \\
\text { load }\end{array}$ \\
\hline yrs & & cells $/ \mathrm{mm}^{3}$ & $\begin{array}{c}\text { RNA } \\
\text { copies/mL }\end{array}$ & cells $/ \mathrm{mm}^{3}$ & $\begin{array}{c}\text { RNA } \\
\text { copies/mL }\end{array}$ \\
\hline $20-25$ & 9 & 427 & 4.313 & 383 & 3.270 \\
\hline $26-31$ & 36 & 438 & 3.987 & 401 & 4.373 \\
\hline $32-37$ & 57 & 378 & 19.742 & 626 & 2.460 \\
\hline $38-43$ & 12 & 475 & 3.280 & 419 & 3.351 \\
\hline $\begin{array}{l}\text { Mean } \\
\text { counts }\end{array}$ & 429 & 7.830 & 457 & 3.363 & 70.05 \\
\hline $\begin{array}{l}\text { Negative } \\
\text { Controls }\end{array}$ & 750 & - & - & - & 76.19 \\
\hline
\end{tabular}

among various age groups of the study population. There was no association between age groups and prevalence of STIs. Table 3 shows the differences between the prenatal and postnatal CD4+ and HIV viral loads among the various age groups of HIV seropositive pregnant women. The results show a range of 373 to 475 for the CD4+ cells $/ \mathrm{mm}^{3}$ for the HIV seropositive pregnant women, a range that is significantly lower than those for the seronegative pregnant women. Also the lowest CD4+ cell count of 378 cells $/ \mathrm{mm}^{3}$ and the highest HIV viral load of 19,742 RNA copies/mL were found in the 3237 year age group, showing a correlation between high viral load and low CD4+ cell numbers. In the 
Table 4. Prenatal and postnatal CD4+ counts, HIV viral load and liver enzymes in HIV-HBV co-infected pregnant and normal control women.

\begin{tabular}{|l|c|c|c|} 
& $\begin{array}{c}\text { Normal } \\
\text { Control }\end{array}$ & $\begin{array}{c}\text { HBV } \\
\text { alone }\end{array}$ & $\begin{array}{c}\text { HIV-HBV } \\
\text { Pre-Postnatal }\end{array}$ \\
\hline $\begin{array}{l}\text { CD4+ cells (cells/mm3 } \\
\text { HIV load }\end{array}$ & 750 & 781 & $327-387$ \\
\hline RNA copies/mL) & - & - & $8.787-4.705$ \\
\hline ALT enzyme (IU/L) & 19 & 22 & $59-75$ \\
\hline Creatinine (mg/dL) & $0.5-1$ & 50 & $43-50$ \\
\hline Bilirubin $(\mathrm{mg} / \mathrm{dL})$ & 1.5 & 7 & $11-35$ \\
\hline
\end{tabular}

postnatal period, the highest CD4+ count of 626 cells $/ \mathrm{mm}^{3}$ and the lowest HIV viral load were also recorded among the 32-37 year age group, indicating an improvement in the health status of the women in that age group after child delivery. The results did not show any correlation between age and viral load, nor with CD4 cell counts among the HIV seropositive women. We did additional analysis with the seven pregnant women who had HIV/HBV coinfection. The results of their CD4+ cell counts, HIV viral loads, liver enzymes of alanine aminotransferase $(A L T)$, creatinine and bilirubin are presented in Table 4. The results show that the mean CD4+ cells in normal seronegative pregnant women was 750 cells $/ \mathrm{mm}^{3}$, 781 cells $/ \mathrm{mm}^{3}$ for women with HBV monoinfection, 429-457 cells/mm $\mathrm{mm}^{3}$ for HIV monoinfected women and 327-387 cells $/ \mathrm{mm}^{3}$ for prenatal and postnatal HIV-HBV coinfected women. These results show the CD4+ adverse reducing effect of HBV infection in HIV seropositive women. Table 4 also shows that the mean prenatal and postnatal plasma HIV viral loads for the HIV-HBV coinfected women were respectively 8,787 and 4,705 RNA copies $/ \mathrm{mL}$, which were significantly much higher than the 7,830 and 3,363 RNA copies/mL for the HIV mono-infected women. These numbers again show a correlation between increased HIV viral load and lower CD4+ cell counts. The results also show that the prenatal mean titers of ALT (59 IU/L), creatinine $(43 \mathrm{mg} / \mathrm{dL})$ and bilirubin $(11 \mathrm{mg} / \mathrm{dL})$ and also the post- natal titers of HIV-HBV coinfected women were 10 -20 times higher than those of normal seronegative women. These increases in the liver enzyme titers reflect the deleterious inflammatory effect of $\mathrm{HBV}$ co-infection in HIV seropositive women.

\section{Discussion}

The study investigated the prevalence of coinfection of HIV with selected sexually transmitted infections as well as their effects on the CD4 + cell counts, plasma HIV viral loads, and liver enzymes among 114 HIV seropositive pregnant women at antenatal clinics in Akure, Ondo State between November 2014 and December 2015. HIV seronegative pregnant women in the third trimester of pregnancy served as controls. The study revealed the remarkable effect of STI co-infections in the prognosis of HIV infection among HIV seropositive pregnant women. Sixty two (54.4\%) of the HIV seropositive pregnant women had a co-infection of one or more $\mathrm{STI}$, compared to 18 (14.3\%) of HIV seronegative pregnant women. Interestingly, 31 (50\%) of the 62 HIV seropositive pregnant women with STI coinfections had a co-infection of $T$. vaginalis, while five to seven co-infected women had a co-infection with HBV, HSV-2, HPV-6, T. pallidum and N. gonorrhoeae. These observations would suggest and that STIs, particularly T. vaginalis, may constitute a significant risk factor for HIV susceptibility in women. The preponderance of $T$. vaginalis infection among HIV seropositives is particularly interesting in many instances [12], as other studies have noted that $T$. vaginalis infection may expand the portal of entry for HIV in exposed individuals, thus facilitating HIV transmission and increasing HIV shedding $[13,14]$. Investigators have reported that wet mount procedure that is often used for $T$. vaginalis screening seems to have a low sensitivity of about $70 \%$. Nonetheless, clinical symptoms have been used to supplement the diagnosis of infected patients [15]. Findings from this and other studies suggest that $T$. 
vaginalis and HIV may predispose one to another and vice versa [14]. Given the current availability of antiretroviral drugs in developing countries and the contribution of $T$. vaginalis infection on HIV transmission, it is evident that appropriate and prompt treatment of $T$. vaginalis infection would be essential to reducing the incidence of HIV infection [14].

Some studies have reported that HBV and HIV coinfection may not play a significant role in HIV disease progression [16] but that antiretroviral therapy may increase the risk of hepatotoxicity when starting HIV therapy [17] and also elevating the risk of hepatic flares when active treatment for both HIV and HBV is disrupted [18]. The effects of HIV coinfection with HBV on CD4 cell counts, HIV viral load and liver enzymes were also evaluated in our study. While the ALT value in normal individuals is $\leq 19 \mathrm{IU} / \mathrm{L}$ for women, the value was however elevated in HIV-HBV coinfection. ALT is a marker of liver inflammation or other hepatocyte damage. However, it has been shown that normal ALT levels can also be associated with liver disease progression, particularly in HBeAg negative and HIV coinfected patients. Our results show that the mean CD4+ T cell counts and plasma viral loads among the 7 individuals both at antenatal and post natal periods were significantly different. We also noted abnormal high titers of ALT of $59-75 \mathrm{IU} / \mathrm{L}$, creatinine at $43-50 \mathrm{mg} / \mathrm{dL}$ and total bilirubin of $11-35 \mathrm{mg} /$ $\mathrm{dL}$ at both antenatal and postnatal periods. These high values in Table 4 are indicative of progressive liver damage $[19,20,21]$. Analysis of the profile of the four others with three HIV-HBV-TV coinfections showed a mean CD4+ T cell count of 314.75 cells/ $\mathrm{mm}^{3}$ compared to 405.3 cells $/ \mathrm{mm}^{3}$ for three individuals with only HIV-HBV coinfection. The mean viral load of the women with three coinfections was 4,375.5 RNA copies/mL, compared to 1,255 RNA copies/mL for the HIV-HBV coinfected individuals, thus representing a threefold decrease. The results of this study suggest that HIV coinfection with $T$. vaginalis may amplify and facilitate HIV infection. Our study is important in that it comprehensively eva- luated the effect of STIs in HIV progression among HIV seropositive women in the third trimester of their pregnancy. The pathological complications to mother and fetus that may result from HIV-STI coinfections may result in multiple organ damage and lead to severe development fetal complications as well maternal morbidity and mortality.

\section{Conclusion}

In conclusion, our study showed the high prevalence of STIs among HIV seropositive pregnant women, with about a four-fold increase (54.4\%) over the $14.3 \%$ prevalence among the HIV seronegative controls. The study also revealed that $T$. vaginalis was the predominant STI among the HIV-STI coinfected seropositive group (50\%) as compared to the $22.2 \%$ among the HIV seronegative mothers. The study compared the mean CD4+ cell count, plasma viral load and liver enzymes among selected 7 individuals with HIV-HBV coinfection and showed that the mean CD4+T cell and plasma viral load at antenatal period was 327cells/mm $\mathrm{mm}^{3}$ and 8,787 RNA copies/mL respectively while mean $C D 4+T$ cell count and plasma viral load at postnatal period were 337.25 cells $/ \mathrm{mm}^{3}$ and 4,705 RNA copies/mL Similarly, results from the liver enzymes (ALT, creatinine, total bilirubin) also revealed no significant difference in values in both the antenatal and postnatal period among the subjects $[17,18]$.

\section{Limitation of the Study:}

The sensitivity of the techniques employed may have posed some limitation in the study. The detection of $T$. vaginalis by wet mount, syphilis by non treponemal rapid plasma reagin and $C$. trachomatis may have lowered sensitivity values. We are nonetheless, aware of sensitive techniques such as nucleic acid test (NAT) for gonorrhoea as well as immunofluorescence for DNA amplification for $C$. trachomatis both of which are often not available in resource constraint centers. 


\section{Acknowledgement}

The authors acknowledge the clinical assessment of study participants by Drs. P.O. Osho, V. Koledoye and Akintan Adesina, the nursing staff and laboratory technologists at the four healthcare centres at Akure in Ondo state of southwestern Nigeria.

\section{Conflicts of Interest}

The authors declare no conflicts of interest.

\section{References}

1. Klouman, E., Manongi, R. and Klepp, K. (2005). Self-reported and observed female genital cutting in rural Tanzania: associated demographic factors, HIV and sexually transmitted infections article first published online: Tropical Medicine and International Health, 7(9): 345-352.DOI: 10.1111/j.1365-3156.2004.01350

2. WHO (2011). 7 management of hepatitis and HIV coinfection: Clinical protocol for WHO European region. pp1-31

3. Mbizvo, M. T., Machekano, R., McFarland, W., Ray, S., Bassett, M, and Latif, A. (1996). HIV seroincidence and correlates of seroconversion in a cohort of male factory workers in Harare, Zimbabwe. AIDS, 10: 895-901. doi: 10.1097/00002030199607000-00013. [PubMed] [Cross Ref]

4. Fleming DT, Wasserheit JN. (1999).From epidemiological synergy to public health policy and practice: The contribution to other STDs to sexually transmission of HIV infection. Sex Transm Infect 73:3-17

5. Mosha, F., Nicoll, A., Barongo, L., Borgdorff, M., Newell, J., Senkoro, K., Grosskurth, H., Changalucha, J., Klokke, A. and Killewo, J. Z. (1993). A population-based study of syphilis and sexually transmitted disease syndromes in northwestern Tanzania: prevalence and incidence. Genitourinary Medicine, 69: 415-420.

6. Custer B, Sullivan SD, Hazlet TK, IloejeU, Veenstra DC and Kowdley KV. (2004). Global epidemiology of hepatitis B virus. Journal of Clinical Gastroneurology:38S158-S168

7. Laga, M., Nzila, N., Goeman, J. (1991). "The interrelationship of sexually transmitted diseases and HIV infection: implications for the control of both epidemics in Africa". AIDS5 (Suppl 1): S55S63. PMID1669925.

8. Tovanabutra S, Robison V, Wongtrakul J, et al. (2002). "Male viral load and heterosexual transmission of HIV-1 subtype $\mathrm{E}$ in northern Thailand". J. Acquir. Immune. Defic. Syndr. 29 (3): 275-283. PMID11873077.

9. Turantola A, Abiteboul D, Rachline A. (2006). Infection risks following accidental exposure to blood or bloody fluids in health care workers: A review of pathogens transmitted in public cases. American Journal of Infection Control. 34:367-375
10. Partec GmbH. (2006). Counting of CD4+ T-Cells with CyFlow ${ }^{\circledR}$ Counter and Partec CD4 easy count kit, package insert. OttoHahn-Str. 32, D-48161 Münster, Germany.

11. Roche, 2013. Quantification of HIV-1 plasma viral load with COBAS $^{\circledR}$ AmpliPrep/COBAS ${ }^{\circledR}$ TaqMan ${ }^{\circledR}$ HIV-1 Qual Test. Roche Molecular System, Inc., Branchburg NJ 08876 USA.

12. Bhunu CP and Mushayabasa S. (2015).Transmission dynamics of Trichomonas vaginalis and HIVIAIDS coinfection. HIVIAIDS review. Vol 14(4):126-132. Doi 10.1016/j.hivar.2015.05.005

13. Fichorova RN (2009) Impact of Trichonomas vaginalis infection on innate immune responses and reproductive outcome. J reprod immunol 83(1-2)185-189.

14. Sorvillo F, Smith L, Kerndt $P$ and Ash L (2001) Trichomonas vaginalis HIV and African-Americans. Centres for Disease control and prevention emerging Infectious Disease. Vol7(6)

15. Wolner Hanssen P, Krieger JN, Stevens CE, Kiviat NB, Koutsky L, Critchlow C, DeRouen T, Hilliers S and Holmes KK.(1989). Clinical manifestation of vaginal trachomatics. JAMA 261(4)571-6

16. Mavedzenge Sn, pl Bv cheng H, Montogomery ET, Blanchard K, Bruyn G, Ramjee G and Straten A. V. 2010. Epidemiological synergy of Trichomonas vaginalis and HIV in Zimbabwean and South African women. Sexually Transmitted Disease. 37(7)460-466

17. Eskild A, Magnus P, Petersen G et al., 1992. Hepatitis B antibodies in HIV-infected homosexual men are associated with more rapid progression to AIDS. AIDS 6(6)571-4

18. Gilson RJ, Hawkins AE, Beecham et al 1997. Interaction between HIV and hepatitis B in homosexual men: effects on the natural history of infection. AIDS 11(5)597-606

19. Chauvel O, Lacombe K, Bonnard p et al. (2007). Risk factors for acute liver enzymes abnormalities in HIV- hepatitis B virus coinfected patients on antiretroviral therapy. Antivir Ther 12(7)1115-26

20. Mata-Marin JA, Gaytan-Martinez j, Grado-Chavarvia BH, Fuentes-Allen JU, Alfaw-Mejia A. 2009. Correlation between HIV viral load and aminotransferases as liver damage markersbin HIV infected naaive patients: a concondance cross sectional study.

21. Ejileme AA Nwauche CA and Ejele OA. 2007. Pattern of abnormal liver enzymes in HIV patients presenting at a Nigerian Tertiary Hospital. Niger postgrad med J. 14(4):306-9

\section{Publish in International Archives of Medicine}

International Archives of Medicine is an open access journal publishing articles encompassing all aspects of medical science and clinical practice. IAM is considered a megajournal with independent sections on all areas of medicine. IAM is a really international journal with authors and board members from all around the world. The journal is widely indexed and classified Q1 in category Medicine. 